\title{
Enhanced remediation of pollutants by microorganisms-plant combination
}

\author{
M. Supreeth ${ }^{1}$ (1)
}

Received: 11 December 2020 / Revised: 6 March 2021 / Accepted: 22 April 2021 / Published online: 7 June 2021

(C) Islamic Azad University (IAU) 2021

\begin{abstract}
The pollutants have become ubiquitous in the total environment (water, soil and air) due to human activities and they are hazardous to all forms of life on the earth. This problem has made scientists focus on mitigating or complete reduction in pollutants by several means. Microorganism and plants are known to scavenge pollutants. Both are studied enormously in reducing, refining, and removing pollutants from the environment successfully. But, their slow process for removal is disadvantage. However, according to recent advancements in the abatement of pollutants, a combined system of both microorganisms and plant has shown to enhance the remediation of pollutants to an efficient level. In a nutrient-depleted pollutant-rich environment, when suitable plant and microorganisms are introduced, the plant interacts with the rhizosphere and root associate with microorganisms to survive in toxic conditions. The chemicals released by plants signal the microorganisms for interactions. This interaction leads in higher germination efficiency and enhanced root elongation which results in enhanced degradation of pollutants in both rhizosphere and phyllosphere. In this background, the current review article provides an overview of the recent advancement in microorganisms plant combined systems in enhanced removal of several recalcitrant pollutants. The conclusion highlights the challenges and future perspectives in this area of research.
\end{abstract}

Keywords Bioremediation · Environment $\cdot$ Pollutants $\cdot$ Pollution

\section{Introduction}

The total environment, which includes water, soil, and air ecosystems, has been adversely affected by the activities carried out by human beings around the globe, and his activities are changing the earth due to pollution (Hill 2020). The effect of environmental pollution (water, soil, and air) is increasing due to accelerated industrialization and urbanization throughout the world. This has resulted in more than twelve million deaths worldwide and twenty-two percent of the global burden of disease in 2012. More than one million children younger than five years of age die each year due to living in a polluted environment (Xu et al. 2018a). There are numerous reports on the effect of pollution on human health.

Editorial responsibility: Maryam Shabani.

M. Supreeth

supreeth@jssuni.edu.in

1 Department of Microbiology, Faculty of Life Sciences, JSS Academy of Higher Education \& Research, Mysuru 570015, India
Some effects include, (1) usage of synthetic chemicals, and the presence of heavy metals in nature threatens integral reproducibility in males (Jenardhanan et al. 2016). (2) Environmental pollutants lead to change in gut microbiota which alters the host immune system and influences in host's energy metabolism, nervous system, cardiovascular system, and endocrine system, either directly or indirectly (Jin et al. 2017). (3) Human milk has been detected with polychlorinated biphenyls and heavy metals such as arsenic, lead, cadmium, and mercury (Pajewska-Szmyt et al. 2019). These effects result in several physiological, mental, economic, and social status of society. As the pollution level increases, health expenditures also increase (Hao et al. 2018). Pollution will impact societal development and condemns future generations to continue poverty and endless poor health encourages social unrest, war, and migration (Landrigan and Fuller 2015). The only solution to these problems is to bring down the pollution levels. From recent lockdown around the globe due to the outbreak of COVID-19 pandemic where most human activities were halted, resulted in the reduction in pollution and nature reclaiming itself. This showed the world how to reduce pollution on a long-term basis (Muhammad 
et al. 2020). However, the total shutdown or lockdown of human activities to bring down the pollution levels cannot be accepted by stakeholders or policymakers owing to an economic crisis. The next best option to remove is through biological means. Biological methods include microbial bioremediation (bacterial remediation, mycoremediation, phycoremediation), enzymatic remediation, vermiremediation, phytoremediation, and zooremediation. Microorganisms alone have the potential to remove pollutants to some extent. Literature studies state that, bioremediation using microorganisms and phytoremediation using plants is the cheapest method employed for the removal of pollutants. Their slow process for removal is a disadvantage. However, a combined system of both plants and microorganisms can enhance the remediation process to an efficient level. The Plant-Microbe rhizoremediation provides several advantages, including the degradation of pollutants, uptake by plants, sorption of pollutants, and enhancement of plant tolerance towards pollutants (Nasr 2019). Considering this, this review focuses on recent research on the microorganisms-plant combination in the successful enhancement of remediation of pollutants of the total environment.

\section{Remediation of pollutants}

Active management strategies (Physical and Chemical) can help preserve and restoring conservative total environment systems. However, these methods are not efficient, costeffective, and not enough to mitigate pollutants due to the continuous regeneration of recalcitrant pollutants by anthropogenic activities (Dangi et al. 2019). Phytoremediation of contaminants by plants and biodegradation of contaminants by microorganisms alone is often not complete because of phytotoxicity and/or evapotranspiration of pollutants. However, a biological process performed by microorganisms and plants could be combined to clean up the hazardous pollutants in the total environment (Mandal et al. 2016; Mishra et al. 2020; Weyens et al. 2009). Microorganisms can be employed in the biodegradation of all types of pollutants and recalcitrant molecules of complex nature (Thakur 2018). In a nutrient-depleted polluted-rich environment, plants interact with the rhizosphere and root associate with microorganisms to survive in toxic conditions. The chemicals released by plants signal the microorganisms for interactions. Microaerophilic conditions will be provided by plants and also exudate from roots enhances the degradation of contaminants. Plant roots stimulate microorganisms by making pollutants available for microorganisms by first providing the substrates and secondly by altering the $\mathrm{pH}$ (Hussain et al. 2018). The pollutants accumulated in plants can be degraded by microorganisms introduced into the tissues of the plant. When suitable microbial strain is introduced into the pollutant environment with a suitable plant (more absorbance and strong tolerance), the combined system of both plant and microbe together combine with the indigenous population to enhance the bioremediation process by several mechanisms and environmental factors (Erguven, Yildirim and Adar 2017; Kuiper et al. 2004; Lee et al. 2020; Saravanan et al. 2020; Truu et al. 2015; Fig. 1). This Microbe-Plant combined system can revolutionize the industry by bringing economic, environmental, and social benefits to all stakeholders (Abhilash et al. 2012).

\section{Enhanced removal of excess nutrients/ pollutants in aquatic environment}

Nutrient removal from surface water is attracting attention as eutrophicated water can cause severe environmental concerns and even threaten human health (Jiang et al. 2019). A plant-microbe interaction in an aquatic system especially on rhizoplane is common (Srivastava et al. 2017), which can be used in the removal of excess nutrients/pollutants by dual potential candidates. The enhanced removal of various pollutants from water by the combination of microorganisms and plants is given in Table 1 .

Combination of plants (Lolium perenne var. Top One (LPT) and Lolium perenne var. respect (LPR) and microbial species (Bacillus sp. MOE1 and Microbacterium sp. MOE2) enhanced the removal of ammonium nitrogen $\left(\mathrm{NH}_{4}\right.$ $\left.{ }^{+}-\mathrm{N}\right)$, Phosphorus, and $\mathrm{COD}_{\mathrm{Mn}}$ from eutrophicated water (Li et al. 2011). Success in removal of pollutants depends upon concentration of pollutants and presence of plants and plants association with planktonic bacterial communities in water. The study conducted by Xu et al. (2018b), showed that plant species Phragmites australis, Nymphaea alba, and Myriophyllum verticillatum were able to remove organophosphorous pesticide chlorpyrifos from eutrophicated water in which there was influence of planktonic bacterial communities. Enhancement of plant growth was attributed by making carbon available to submerged plant species Vallisneria natans by inoculation of bacterial species Pseudomonas putida KT2440. The Photocooperation between $V$. natans and $P$. putida KT2440 increased the carbon availability (Gan et al. 2018). In another study, four macrophytes (Brachia mutica, Typha domingensis, Phragmites australis, and Leptochala fusca) were used to remove trace elements (Fe, $\mathrm{Mn}, \mathrm{Ni}, \mathrm{Pb}$, and $\mathrm{Cr}$ ) from polluted river water by floating treatment wetlands (FTWs). Enhanced removal of elements was reported when FTWs was inoculated with endophytic bacterial strains Aeromonas salmonicida, Pseudomonas indoloxydans, Bacillus cerus, Pseudomonas gessardii, and Rhodococcus sp. The work showed combination of different species increased in removing heavy metals efficiently than single species (Shahid et al. 2020). 


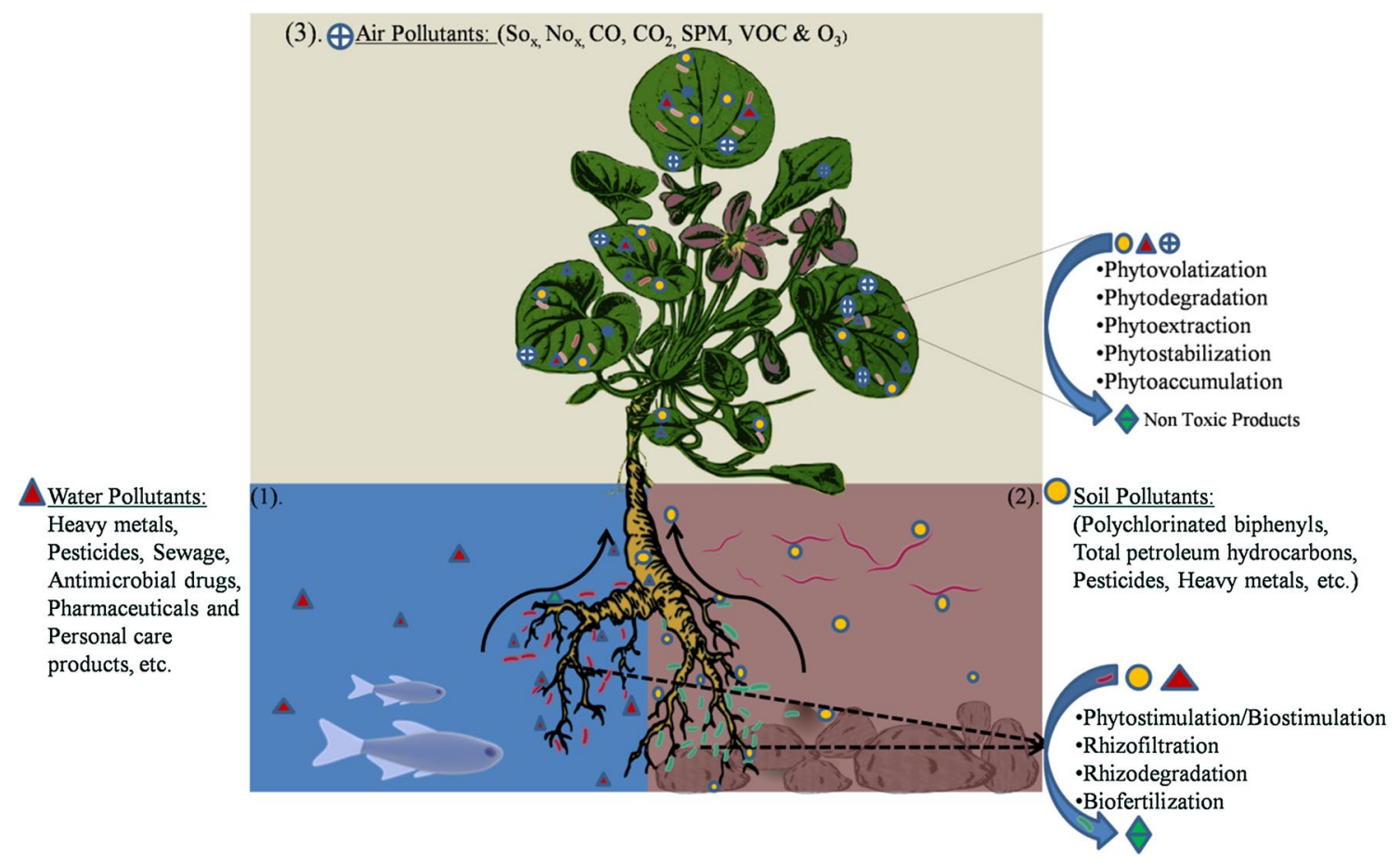

Fig. 1 Mechanism of Microorganism plant interaction in enhanced degradation of pollutants in (1). Water, (2). Soil and (3). Air

Eight plant species Syngonium podophyllum, Sansevieria trifasciata, Euphorbia milii, Chlorophytum comosum, Epipremnum aureum, Dracaena sanderiana, Hedera helix, and Clitoria ternatea were evaluated for removal of benzene in hydroponic conditions. Among them C. comosum showed highest efficiency in removal, a non-sterilized plant which was associated with both endophytic and epiphytic bacteria (Sriprapat and Thiravetyan 2016). Selection of suitable microorganisms in remediation of pollutants plays an important role to reduce the opposite effects of insecticides in agricultural areas (Tatar et al. 2020). Total nitrogen present in eutrophic water body was reduced by combination of immobilized nitrogen cycling bacteria (INCB) with aquatic macrophytes in the study carried out by (Chang et al. 2006). The two seasonal plants Eichhornia crassipes and Elodea nuttallii provided favorable conditions in roots to INCB to colonize. The microorganisms plants jointly removed total nitrogen (TN) by $70.2 \%$, nitrite and ammonium by $92.2 \%$ and $50.9 \%$, respectively. Sauvêtre et al. 2018 worked on removal of pharmaceutical frequently categorized as a recalcitrant pollutant Carbamazepine (CBZ) from aquatic environment by a plant species Armoracia rusticana in combination with Rhizobium radiobacter and Diaphorobacter nitroreducens (10\%). The dual system enhanced the pollutant removal significantly.

Lolium perenne L. and Arabidopsis thaliana $L$ in association with endophytic bacteria Pseudomonas sp. reduced Total petroleum hydrocarbon (TPH)- Diesel significantly.
Application of bacteria reduced phytotoxicity and suggested that inoculation had a positive effect on plant growth under stress conditions as compared to control (without bacteria) Iqbal et al. 2019. The plant Halonemum strobilaceum growing in hyper saline conditions of Arabian Gulf harbor constituted oil utilizing bacteria in phyllosphere and rhizosphere. Frequent genera included yeast Candida utilis and the two proteobacteria Ochrobactrum sp. and Desulfovibrio sp. In rhizosphere, Halobacterium sp. and Halococcus sp., the firmicute Brevibacillus borstenlensis, and the proteobacteria Pseudoalteromonas ruthenica and Halomonas sinaensis was found. All the strains except yeast were found to be excellent degraders of polluted oil. The study concluded that $\mathrm{H}$. strobilaceum could be used to phytoremediation of oil-polluted hypersaline environments via rhizosphere technology (AlMailem et al. 2010).

Under hydroponic conditions, Dracaena sanderiana inoculated with two plant growth-promoting (PGP) bacterial strains, Bacillus thuringiensis and Pantoea dispersa, removed one of the most abundant endocrine-disrupting compounds Bisphenol A (BPA). The Microorganisms-Plant combined system enhanced removal of BPA up to $92.32 \pm 1.23 \%$ (Suyamud et al. 2018). Wu et al. 2016 worked on removal of nitrogen from water by hydroponic condition using three macrophyte species Typha augus tifolia, Phragmites australis, and Acorus calamus L. The three species were fed with synthetic waste water. From the result, it was evident that there was co-relation between 


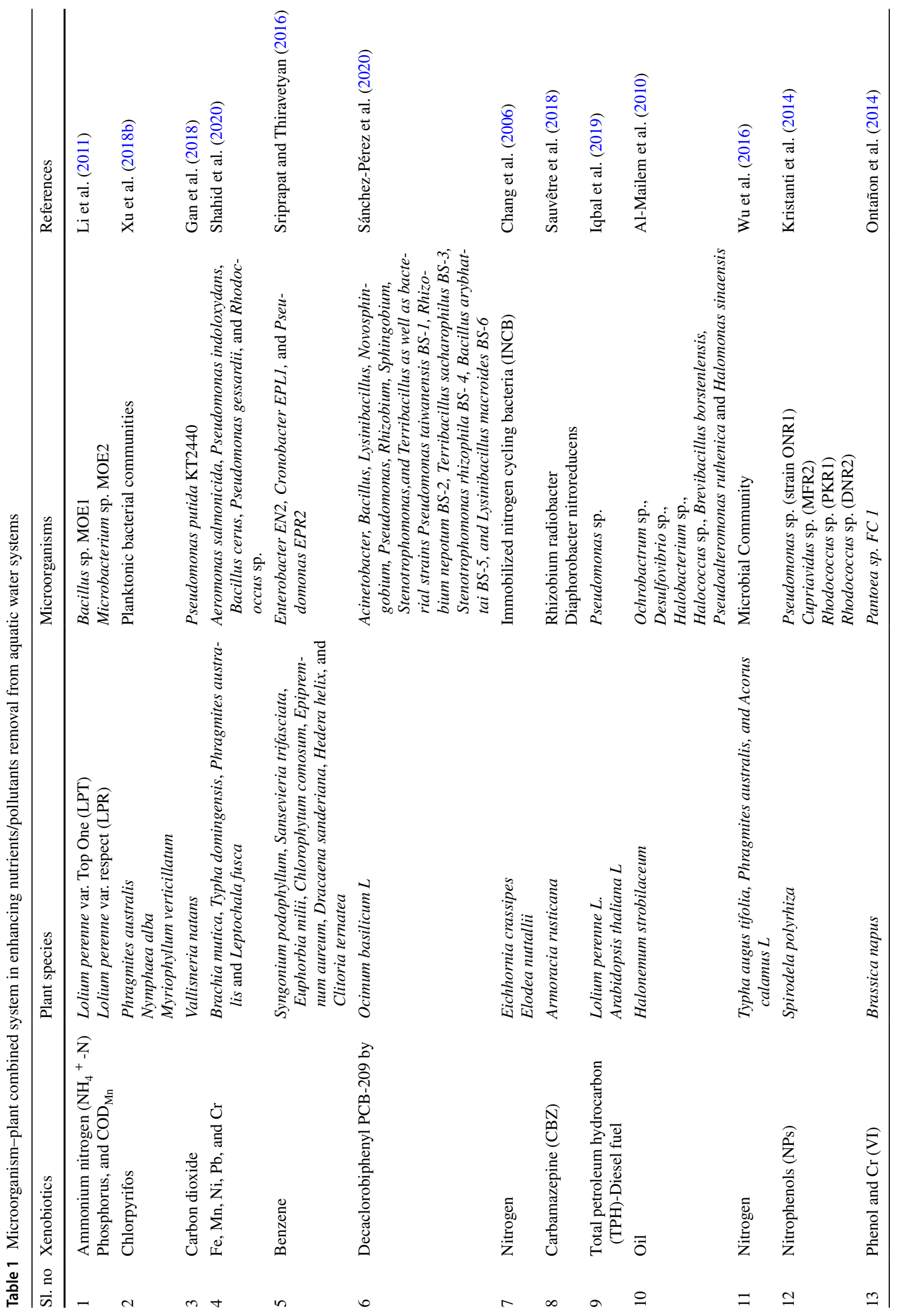


plant biomass and total nitrogen removal with involvement of microbial community. Water contaminated with nitrophenols (NPs), 2-NP, 3-NP, 4-NP, and 2,4-dini- trophenol (2,4-DNP) was rhizoaugmented with NP-degrading bacteria to giant duckweed (Spirodela polyrhiza). The four NPdegrading bacterial strains were found to colonize Spirodela roots resulted in complete removal of NPs within each cycle (Kristanti et al. 2014). The bacterial strain Pantoea sp. FC 1 resistant to phenol and $\mathrm{Cr}(\mathrm{VI})$ used phenol as sole carbon source and also able to reduce $\mathrm{Cr}$ (VI) to $\mathrm{Cr}$ (III). The strain was inoculated into rhizosphere Brassica napus hairy roots (HRs). The efficiency in removal of phenol and reduction from $\mathrm{Cr}$ (VI) to $\mathrm{Cr}$ (III) was improved with combination of both microorganisms and plant (Ontañon et al. 2014). The pollutants included organic substances such as nitrogen and phosphorous, various heavy metals, pesticides, hydrocarbons, phenolic compounds, pharmaceutical wastes, and personal care products.

From the above discussed studies, it is evident that the combination of microorganisms and plant species was successful in enhancing the removal of aquatic pollutants such as excess nutrients, benzene, total petroleum hydrogen (TPH), phenol and pharmaceuticals pollutants. The mechanism behind the removal of these pollutants includes phytostimulation/biostimulation, rhizofiltration, rhizodegradation, and biofiltration.

\section{Enhanced removal of excess nutrients/ pollutants in terrestrial environment}

Soil is the ultimate sink for all pollutants that has been neglected, which resulted in the deterioration of its quality in several sites across the world (Sakshi et al. 2019). The management of soil contaminated with persistent organic pollutants (POPs) by plant-microbe interactions is a lowcost prospective biotechnological approach (Sarma et al. 2019). Microorganisms partnership with plants can be used to overcome problems related to the soil such as salinity, fertility, degradation, and habitat loss (Pandey et al. 2019). There are several successful attempts in the removal of pollutants from the soil by microorganisms-plant combination. The enhanced removal of various pollutants from the soil by the combination of microorganisms and plants is given in Table 2.

Enhanced removal of phenylurea herbicide (PH)- isoproturon (IPU) from contaminated sites was achieved by the action of plant-microbe interactions. Transgenic Arabidopsis thaliana plant converted IPU into to 3-(4- isopropylphenyl)1-methylurea (MDIPU). The released intermediate was further metabolized by the combinedly inoculated MDIPUmineralizing bacterium Sphingobium sp. strain 1017-1 in the rhizosphere, resulting in an enhanced and complete removal of IPU from soil (Yan et al. 2018). Synergistic activity between plant (Saccharum sp.) and yeast (Candida VITJzN04) enhanced removal of organochlorine pesticide lindane $(\sim 100 \mathrm{mg} / \mathrm{kg})$ in ex-situ remediation carried out by (Salam et al. 2017). In another study Cytisus striatus in association with different dual bacterial inoculants was assessed for dissipation of the insecticide hexachlorocyclohexane $(\mathrm{HCH})$. Interaction between the dual bacterial species with Cytisus striatus enhanced the removal of insecticide up to 53\% (Becerra-Castro et al. 2013). Similarly, a recent study on biodegradation of monocrotophos (MCP) by Dash and Osborne 2020 showed enhancement in removal of MCP by Bacillus aryabhattai VITNNDJ5 and Liriope muscari in combination. Two actinobacteria Streptomyces sp. Z38 and Streptomyces $\mathrm{sp}$. Z2 was grown with maize root exudates to remove pesticide lindane and metal $\mathrm{Cr}$ (VI). Good performance in removal of mixed contaminants was observed and also improved plant establishment (Simón Solá et al. 2019).

Shi et al. 2019 also analyzed efficiency of Ectomycorrhizal (ECM) fungi Hebeloma vinosophyllum (Cr (VI)sensitive strain) and Pisolithus sp1 (Cr (VI)-tolerant strain) along with Japanese black pine (Pinus thunbergii) in removal of Cr (VI) from soil. Pisolithus sp1 had a significantly higher accumulation of $\mathrm{Cr}$ than $H$. vinosophyllum in mycelium under the same $\mathrm{Cr}(\mathrm{VI})$ treatments in liquid culture experiment. Accumulation of $17 \alpha$-ethynylestradiol (EE2) in soil and environment due to land application of sewage sludge and animal manure as influenced on human and animal health. He et al. 2019 isolated EE2-degrading bacteria Hyphomicrobium sp. GHH and inoculated with plant Lolium perenne. Inoculation of bacterial isolate increased accumulation of EE2 significantly in the plant and removal of EE2 up to $99 \%$. The interaction between two candidates is having a synergistic effect on the EE2 removal.

Plant-Microorganisms joint interaction in crude oil degradation showed higher efficiency in the rhizospheres of Scorzonera mongolica Maxim., Atriplex centralasiatica, and Limonium bicolour by larger shoot and root biomass than non rhizospheric soil (Ying et al. 2011). Chloronitroaromatic pollutant, 4-chloronitrobenzene (4CNB) was degraded by application of bacteria strain Comamonas sp. strain CNB-1 isolated from activated sludge into rhizosphere of Alfalfa. The pollutant $4 \mathrm{CNB}$ was removed within two days (Liu et al. 2007). Four plant growth promoting bacteria (PGPB) Arthrobacter sp., Bacillus altitudinis, Bacillus megatherium and Sphingomonas were investigated to check the effects of these PGPB on plant growth and Cd accumulation of oilseed rape (Brassica napus) plants grown on aged Cd-spiked soil. Enhanced uptake of Cd was seen in Brassica napus and also there was significance in shoot biomass and Plant Analyzer Development (SPAD) due to combination of both PGPB and Plant (Pan et al. 2017). 
Table 2 Microorganism-plant combined system in enhancing nutrients/pollutants removal from soil environments

\begin{tabular}{|c|c|c|c|c|}
\hline Sl. no & Xenobiotic & Plant species & Microorganisms & References \\
\hline 1 & $\begin{array}{l}\text { Phenylurea herbicide (PH)- } \\
\text { isoproturon (IPU) }\end{array}$ & Transgenic Arabidopsis plant & Sphingobium sp. strain 1017-1 & Yan et al. (2018) \\
\hline \multirow[t]{2}{*}{2} & Lindane & Saccharum sp & Candida VITJzN04 & Salam et al. (2017) \\
\hline & & Cytisus striatus & $\begin{array}{l}\text { Rhodococcus erythropolis } \\
\text { ET54b } \\
\text { Sphin-gomonas sp. D4 }\end{array}$ & Becerra-Castro et al. (2013) \\
\hline 3 & Monocrotophos (MCP) & Liriope muscari & $\begin{array}{l}\text { Bacillus aryabhattai } \\
\text { VITNNDJ5 }\end{array}$ & Dash and Osborne (2020) \\
\hline 4 & Lindane and $\mathrm{Cr}(\mathrm{VI})$ & maize root exudates & $\begin{array}{l}\text { Streptomyces sp. Z38 } \\
\text { Streptomyces } \mathrm{sp} . \mathrm{Z} 2\end{array}$ & Simón Solá et al. (2019) \\
\hline 5 & $\mathrm{Cr}(\mathrm{VI})$ & Pinus thunbergii & $\begin{array}{l}\text { Hebeloma vinosophyllum } \\
\text { Pisolithus } \mathrm{sp} 1\end{array}$ & Shi et al. (2019) \\
\hline 6 & 17 $\alpha$-ethynylestradiol (EE2) & Lolium perenne & Hyphomicrobium sp. GHH & He et al. (2019) \\
\hline 7 & Crude oil & $\begin{array}{l}\text { Scorzonera mongolica Maxim., } \\
\text { Atriplex centralasiatica, and } \\
\text { Limonium bicolor }\end{array}$ & growth-promoting rhizobacteria & Ying et al. (2011) \\
\hline 8 & 4-chloronitrobenzene (4CNB) & Alfalfa & Comamonas sp. strain CNB-1 & Liu et al. (2007) \\
\hline 9 & $\mathrm{As}, \mathrm{Cd}, \mathrm{Pb}$ and $\mathrm{Zn}$ & $\begin{array}{l}\text { Acacia saligna and Eucalyptus } \\
\text { camaldulensis }\end{array}$ & rhizosphere microorganisms & Guarino and Sciarrillo (2017) \\
\hline 10 & Nitrobenzene & $\begin{array}{l}\text { Phragmites australis-JS45 } \\
\text { system }\end{array}$ & $\begin{array}{l}\text { Proteobacteria and } \\
\text { Firmicutes }\end{array}$ & Chi et al. (2018) \\
\hline 11 & Bisphenol A (BPA) & Dracaena sanderiana & $\begin{array}{l}\text { Bacillus thuringiensis and Pan- } \\
\text { toea dispersa }\end{array}$ & Suyamud et al. 2018 \\
\hline 12 & Cadmium $(\mathrm{Cd})$ & poplar (clone "I-214”) & Pseudomonas fluorescens & Cocozza et al. (2014) \\
\hline 13 & Dioxin & Trifolium repens $L$ & Comamonas sp. strain KD7 & Wang and Oyaizu (2011) \\
\hline 14 & $\begin{array}{l}\text { Polycyclic aromatic hydrocar- } \\
\text { bons (PAHs) and heavy metals } \\
(\mathrm{Cd} \text { and } \mathrm{Zn})\end{array}$ & ryegrass & $\begin{array}{l}\text { Microbacterium sp. KL5 } \\
\text { Candida tropicalis } C 10 \text { in }\end{array}$ & Chen et al. (2016) \\
\hline 15 & $\begin{array}{l}\text { Lead }(\mathrm{Pb}) / \text { zinc }(\mathrm{Zn}) / \text { cadmium } \\
\quad(\mathrm{Cd})\end{array}$ & $\begin{array}{l}\text { Sedum plumbizincicola } \\
\text { Sedum plumbizincicola }\end{array}$ & Bacillus sp. SC2b & Ma et al. 2015 \\
\hline 16 & $\mathrm{Ni}, \mathrm{Cr}$, and $\mathrm{Cd}$ & Brassica juncea & $\begin{array}{l}\text { Pseudomonas aeruginosa } \\
\text { KP717554 } \\
\text { Alcaligenes feacalis KP717561 } \\
\text { Bacillus subtilis KP717559 }\end{array}$ & Ndeddy Aka and Babalola (2016) \\
\hline 17 & $\mathrm{As}, \mathrm{Cd}, \mathrm{Cu}, \mathrm{Pb}$, and $\mathrm{Zn}$ & Lupinus luteus & Serratia sp. MSMC541 & El Aafi et al. (2012) \\
\hline
\end{tabular}

Integrated Phytoremediation System (IPS) was applied for removal of heavy metals $\mathrm{As}, \mathrm{Cd}, \mathrm{Pb}$ and $\mathrm{Zn}$ in soil. The two plant species Acacia saligna and Eucalyptus camaldulensis along with rhizosphere microorganisms showed considerable amount of pollutants removal (Guarino and Sciarrillo 2017). (Chi et al. 2018) conducted experiments for removal of nitrobenzene from sediments using Phragmites australis-JS4. The efficiency of removal of nitrobenzene was not significant by Phragmites australis-JS4 alone. However the pollutant was degraded with twenty days by indigenous microorganism which was quantified using real-time polymerase chain reaction. Enhanced remediation of dioxin contaminated soil by dibenzofuran-degrading bacterial strain Comamonas sp. KD7 and Plant Trifolium repens $L$ was reported by (Wang and Oyaizu 2011). After twelve weeks of growth, significance in reduction in dioxin was achieved. Green house study conducted by Chen et al. 2016 to remove polycyclic aromatic hydrocarbons (PAHs) and heavy metals $(\mathrm{Cd}$ and $\mathrm{Zn}$ ) from soil by microbe-plant combination revealed that, ryegrass with Seduce alfredii inoculated with microbial strains Microbacterium sp. KL5 and Candida tropicalis $\mathrm{C} 10$ removed the pollutants in to be below standard limit.

Removal of oil refinery sludge by association of plant growth-promoting rhizobacteria and polycyclic aromatic hydrocarbon-degrading bacteria in combination with pasture plants was carried out by (Pizarro-Tobias et al. 2015). The combination of both microorganisms and plant was able to remove total hydrocarbons within seven months compared to control soil site which was carried out only by plant. Presence of three grass species Cymbopogon ambiguus, Brachiaria decumbens, and Microlaena stipoides increased the 
efficiency of microorganisms in removing remediation of diesel/oil contaminated soil, without any requirement for nutrient supplementation (Gaskin and Bentham 2010). Plant growth-promoting bacteria (PGPB) Bacillus sp. SC2b was used as metal mobilizing bioinoculant for rhizoremediation of soils polluted with metals lead $(\mathrm{Pb}) /$ zinc $(\mathrm{Zn})$ and cadmium $(\mathrm{Cd})$. The bacterial strain was inoculated into rhizosphere of plant Sedum plumbizincicola and Brassica napus which resulted in mobilization of high concentration of heavy metals from soils (Ma et al. 2015). Another study carried out by (Kanat et al. 2018) showed control and preventive measures of heavy metals contamination. Similarly heavy metal (Ni, Cr, and $\mathrm{Cd}$ ) was removed by combination of Brassica juncea and three bacterial strains Pseudomonas aeruginosa KP717554, Alcaligenes feacalis KP717561, and Bacillus subtilis KP717559. Inoculation of these three bacterial strains improved germination of $B$. juneca and also significance in solubilization of heavy metals (Ndeddy Aka and Babalola 2016). The plant Lupinus luteus grown in soil and was supplemented with heavy metal along with inoculation of bacterial strain Serratia sp. MSMC541. Inoculation of bacterial strain improved the tolerance of plant species to heavy metals (El Aafi et al. 2012). Apart from these pollutants, solid waste generation is another major problem encountered across the globe. The organic waste which accounts for $40-70 \%$ of total municipal solid waste (MSW) requires attention for its management (Kanat and Erguven 2020).

Soil pollutants included pollutants such as pesticides (herbicides, weedicides and insecticides), heavy metals, total hydrocarbons and other recalcitrant compounds. The combination of microorganisms and plants with single species or combination of several species enhanced the removal of pollutants from soil effectively.

\section{Enhanced removal of excess nutrients/ pollutants in atmosphere}

Air pollution is a major culprit that enhances pulmonary disorders such as asthma, chronic obstructive pulmonary disease, lung cancer, and respiratory infections in susceptible populations, such as children, the elderly, and those of low socio-economic status affecting nine of 10 individuals living in urban areas worldwide (Kurt et al. 2016). Plant-microorganisms combined system can be used to clean up both indoor and outdoor air systems to remove major air pollutants $\left(\mathrm{O}_{3}, \mathrm{PM}_{10}, \mathrm{NO}_{2}, \mathrm{SO}_{2}\right.$, and $\left.\mathrm{CO}\right)$. This can be accomplished by selecting appropriate plant species and specific microbial communities to remove pollutants maximum (Irga et al. 2020). The enhanced removal of various pollutants from atmosphere by the combination of microorganisms and plant is given in Table 3.

Indoor gaseous air pollutant formaldehyde (colorless flammable gas at room temperature with a pungent odor) was removed by interaction between endophytic bacteria Bacillus cereus ERBP and plant species Clitoria ternatea. Sterile seedlings of Clitoria ternatea inoculated with bacterium inoculant increased the efficiency of seed germination and seedling growth under increasing levels of

Table 3 Microorganism-plant combined system in enhancing nutrients/pollutants removal from air

\begin{tabular}{|c|c|c|c|c|}
\hline S1. no & Xenobiotic & Plant species & Microorganisms & References \\
\hline 1 & Gaseous formaldehyde & Clitoria ternatea & Bacillus cereus ERBP & Khaksar et al. (2016) \\
\hline 2 & Formaldehyde & $\begin{array}{l}\text { Helianthus annuus Linn, Lycopersicon } \\
\text { esculentum Miller, Oryza sativa, } \\
\text { Sansevieria trifasciata, Prain, Bryo- } \\
\text { phyllum pinnatum, Mesembryanthe- } \\
\text { mum cor- difolium L. f. Most }\end{array}$ & Rhizobacteria & Zhao et al. (2019) \\
\hline 3 & $\mathrm{O}_{3}$ & Zamioculcas zamiifolia & Bacillus cereus ERBP & Pheomphun et al. (2019) \\
\hline 4 & Formaldehyde & $\begin{array}{l}\text { Tradescantia zebrina Bosse }(T . \\
\text { zebrina) } \\
\text { Aloe vera (Haw.) Ber }(\text { A. vera) } \\
\text { Vigna radiata }(\text { Linn.) Wilczek }(V . \\
\text { radiata) }\end{array}$ & Rhizosphere microorganisms & Yang et al. (2020b) \\
\hline 5 & Toluene & vetiver grass in & Achromobacter xylosoxidans F3B & Ho et al. (2013) \\
\hline 6 & $\begin{array}{l}\text { Phenanthrene, acenaphth- } \\
\text { ylene, acenaphthene, and } \\
\text { fluorine }\end{array}$ & Ornamental Plants & $\begin{array}{l}\text { Acinetobacter, Pseudomonas, Pseu- } \\
\text { doxanthomonas, Mycobacterium, } \\
\text { and uncultured bac- teria. Bacterial }\end{array}$ & Yutthammo et al. (2010) \\
\hline 7 & Formaldehyde & Epipremnит aureum & dynamic microbial community & Wang et al. (2014) \\
\hline 8 & Toluene & $\begin{array}{l}\text { Fittonia verschaffeltii var. argyroneura } \\
\text { and Hoya carnosa, }\end{array}$ & Toluene-Metabolizing Bacteria & Zhang et al. (2013) \\
\hline 9 & Chloromethane & Arabidopsis thaliana was & Hyphomicrobium sp. & Nadalig et al. (2011) \\
\hline
\end{tabular}


formaldehyde (Khaksar et al. 2016). In another study, formaldehyde removal by plants and with or without soil microorganisms were evaluated for removal. The result showed that plant-microorganisms system increased by $0.24-9.53$ fold compared to the plant-only systems (Zhao et al. 2019). In one of the study, $\mathrm{O}_{3}$ was effectively removed in a continuous system by Zamioculcas zamiifolia after addition of endophytic bacteria Bacillus cereus ERBP into Z. Zamiifolia. The bacteria protected plant against $\mathrm{O}_{3}$ stress conditions (Pheomphun et al. 2019). (Yang et al. 2020a) developed an efficient plant-microbe technology to remove formaldehyde by adding cultured microorganism into the rhizosphere of three plant species, Tradescantia zebrina Bosse (T. zebrina), Aloe vera (Haw.) Ber (A. vera) and Vigna radiata (Linn.) Wilczek (V. radiata). Results showed that the plant-microbe system removed efficiently than plant alone. Phenolic pollutant, toluene was removed by vetiver grass in association with endophytic bacteria Achromobacter xylosoxidans F3B by the study conducted by (Ho et al. 2013). The strain F3B protected plants against toluene stress and maintained chlorophyll content of leaves, and a 30\% reduction in evapotranspiration through vetiver leaves. Similarly in another study, toluene was removed by foliage plants, Fittonia verschaffeltii var. argyroneura and Hoya carnosa along with group of rhizosphere bacteria. The study showed rhizosphere microbial community contributes to the phytoremediation potential of indoor foliage plants (Zhang et al. 2013).

Yutthammo et al. 2010 studied on diversity and activity of Polycyclic aromatic hydrocarbons (PAHs) degrading bacteria in the Phyllosphere of ornamental plants. About 1-10\% of Phyllosphere bacteria were able to remove PAHs. Bacterial species such as Acinetobacter, Pseudomonas, Pseudoxanthomonas, Mycobacterium, and uncultured bacteria enhanced the removal of phenanthrene from the leaves. In addition, phyllosphere bacteria on Wrightia religiosa were able to reduce other PAHs such as acenaphthylene, acenaphthene, and fluorine which are considered major urban air pollutants. Botanical filtration of formaldehyde was achieved by combination of dynamic microbial community and plant species Epipremnum aureum. The plant species maintained microbial community which in turn degraded volatile organic compound adsorbed or absorbed by plant root bed (Wang et al. 2014). Chloromethane a major volatile halocarbon air pollutant in stratosphere, responsible for about $15 \%$ of chlorine-catalyzed ozone destruction was degraded by Hyphomicrobium sp. which was isolated from leaves surface of Arabidopsis thaliana (Nadalig et al. 2011).

From the above studies it is evident that, the air pollutants such as gaseous compounds, volatile organic compounds, ozone, and particulate matter were successfully removed by microorganisms plant interaction by several mechanisms such as phytovolatilization, phytodegradation, phytoextraction, phytostabilization and phytoaccumulation.

\section{Conclusion and future studies}

Rapid growth in the economy of countries across the globe and increased human activities on vegetation resulted in the release of several recalcitrant pollutants into the water, soil, and air. The concentration of these pollutants is beyond the threshold limit at present causing several serious health issues to humans and other organisms in the environment.

The success of removing pollutants from polluted sites by biological methods depends on the interaction between appropriate microorganisms and plants. From the abovementioned studies conducted by several research across the globe, it is evident that, the special characters adopted by microorganisms to tolerate high concentrations of several recalcitrant pollutants and capacity to colonize the roots of plants and their presence in phyllosphere make them excellent candidates for bioremediation of almost all kinds of pollutants present in water, soil and air. These kinds of organisms can be exploited at an industrial level to clean up the pollutants. The removal of pollutants by the combination of microorganisms and plant combine system gives several benefits over other methods in removing pollutants. First, they are cost-effective, eco-friendly, easy to manage and secondly they increase the green cover and provide shelter for many other organisms living in the biosphere. Most of the water bodies and more than 300 sites in India are contaminated by several pollutants and people living in those areas are unaware of it. The need of the hour is to use microorganisms plant combined system to decontaminate those sites.

Another serious problem faced by most of the countries across the globe is air pollution. This is a serious concern because, on an average, a person inhales $6-10 \mathrm{~L}$ of air per minute, which amounts to 15,000 1/day (Gawrońska and Bakera 2015). Countries like India and many other countries of Asia are witnessing most of the deaths because of breathing polluted air. The scientific solution has been shown by many. Nowak et al. 2014 reported that the trees and forests in the United States removed 17.4 million tons of air pollutants in 2014. Recent work carried out by Franzetti et al. 2020 states that plant microorganisms interaction can remove the pollutants from urban air. This method of remediation can be exploited commercially by selecting suitable microbial strains and plant species. The commercial scale of remediation of water, soil, and air pollutants using microorganisms plants combination is an emerging concept. The real cost in managing these contaminants should be scaled up and it should be made available in the market so that government, non-government organization, environmentalist, and the public can engage in remediation/managing of pollutants both in indoor and outdoor environments.

Challenges in this field of research are many. Firstly, the combination of multiple species of plants and 
microorganisms together enhanced in removing few pollutants and combination of single species of plant and microorganism enhanced in removing some pollutants present in total environment. These observations reveal that, selection of appropriate plant and its associated microorganism in removing pollutants is essential to clean up the specific pollutant. The factors behind these are still unclear and require further attention. For practical application of microorganisms-plant combined system to remediate the contamination in industrial level, it is very much essential to come out with scale-up studies before commercialization. Another challenge in this field lies in the bioaccumulation of pollutants by plants and its disposal after remediation process, which impacts the food chain and environment. Next challenge is biotransformed products. The indiscriminate use of the pesticides has inflicted serious harmful problems to humans in the ecosystem (Yildirim et al. 2018). During the pesticide remediation process, biotransformed products formed should also be studied for its toxicity and affectivity before coming to conclusion of successful remediation because many of the transformed products are toxic or more toxic than their parent compounds (Supreeth and Raju 2017).

Future research should focus on the Plants Microbial Fuel Cells and Constructed-Wetland Microbial Fuel Cells technologies which incorporate plants with combination of bacteria to remove pollutants and also generating bio-electricity. Finally, elucidating actual genes and proteins responsible for pollution remediation and to make the process much easier, faster, and economical by microorganisms and plant combination with the help of genomics, metagenomics, metaproteomics, metatranscriptomics, and metabolomics by omics approaches is required.

Acknowledgements The Author is grateful to JSS Academy of Higher Education \& Research, Mysuru, India, for providing financial and infrastructural support.

\section{Declarations}

Conflict of interest The authors declare no conflict of interest.

Human and animal rights This article does not contain any studies with human participants or animals performed by any of the authors

\section{References}

Abhilash PC, Powell JR, Singh HB, Singh BK (2012) Plant-microbe interactions: novel applications for exploitation in multipurpose remediation technologies. Trends Biotechnol 30:416-420. https:// doi.org/10.1016/j.tibtech.2012.04.004

Al-Mailem DM, Sorkhoh NA, Marafie M et al (2010) Oil phytoremediation potential of hypersaline coasts of the Arabian Gulf using rhizosphere technology. Bioresour Technol 101:5786-5792. https://doi.org/10.1016/j.biortech.2010.02.082

Becerra-Castro C, Kidd PS, Rodríguez-Garrido B et al (2013) Phytoremediation of hexachlorocyclohexane $(\mathrm{HCH})$-contaminated soils using Cytisus striatus and bacterial inoculants in soils with distinct organic matter content. Environ Pollut 178:202-210. https://doi.org/10.1016/j.envpol.2013.03.027

Chang HQ, Yang XE, Fang YY et al (2006) In-situ nitrogen removal from the eutrophic water by microbial-plant integrated system. J Zhejiang Univ Sci B 7:521-531. https://doi.org/10.1631/jzus. 2006.B0521

Chen F, Tan M, Ma J et al (2016) Efficient remediation of PAHmetal co-contaminated soil using microbial-plant combination: a greenhouse study. J Hazard Mater 302:250-261. https://doi. org/10.1016/j.jhazmat.2015.09.068

Chi X, Zhang Y, Wang D et al (2018) The greater roles of indigenous microorganisms in removing nitrobenzene from sediment compared with the exogenous Phragmites australis and strain JS45. Front Environ Sci Eng 12:1-11. https://doi.org/10.1007/ s11783-018-1016-0

Cocozza C, Vitullo D, Lima G et al (2014) Enhancing phytoextraction of Cd by combining poplar (clone "I-214") with Pseudomonas fluorescens and microbial consortia. Environ Sci Pollut Res 21:1796-1808. https://doi.org/10.1007/s11356-013-2073-3

Dangi AK, Sharma B, Hill RT, Shukla P (2019) Bioremediation through microbes: systems biology and metabolic engineering approach. Crit Rev Biotechnol 39:79-98. https://doi.org/10. 1080/07388551.2018.1500997

Dash DM, Osborne JW (2020) Biodegradation of monocrotophos by a plant growth promoting Bacillus aryabhattai (VITNNDJ5) strain in artificially contaminated soil. Int J Environ Sci Technol 17:1475-1490. https://doi.org/10.1007/s13762-019-02432-1

El Aafi N, Brhada F, Dary M et al (2012) Rhizostabilization of metals in soils using Lupinus luteus inoculated with the metal resistant rhizobacterium Serratia sp. MSMC541. Int J Phytoremediation 14:261-274. https://doi.org/10.1080/15226514.2011. 604693

Erguven GO, Yildirim N, Adar E (2017) The ability of Phanerochaete chrysosporium (ME446) on chemical oxygen demand remediation in submerged culture medium supplemented with malathion insecticide. Desalin Water Treat 94:231-235. https://doi.org/10. 5004/dwt.2017.21556

Franzetti A, Gandolfi I, Bestetti G et al (2020) Plant-microorganisms interaction promotes removal of air pollutants in Milan (Italy) urban area. J Hazard Mater. https://doi.org/10.1016/j.jhazmat. 2019.121021

Gan L, Zhao H, Wang A et al (2018) Pseudomonas putida inoculation promotes submerged plant Vallisneria natans growth by carbon conversion in a plant-microbe interaction. Mar Freshw Res 69:851-858. https://doi.org/10.1071/MF17117

Gaskin SE, Bentham RH (2010) Rhizoremediation of hydrocarbon contaminated soil using Australian native grasses. Sci Total Environ 408:3683-3688. https://doi.org/10.1016/j.scitotenv.2010.05.004

Gawrońska H, Bakera B (2015) Phytoremediation of particulate matter from indoor air by Chlorophytum comosum L. plants. Air Qual Atmos Heal 8:265-272. https://doi.org/10.1007/ s11869-014-0285-4

Guarino C, Sciarrillo R (2017) Effectiveness of in situ application of an integrated phytoremediation system (IPS) by adding a selected blend of rhizosphere microbes to heavily multi-contaminated soils. Ecol Eng 99:70-82. https://doi.org/10.1016/j.ecoleng.2016. 11.051

Hao Y, Liu S, Lu ZN et al (2018) The impact of environmental pollution on public health expenditure: dynamic panel analysis based on Chinese provincial data. Environ Sci Pollut Res 25:1885318865. https://doi.org/10.1007/s11356-018-2095-y 
He S, Guo H, He Z et al (2019) Interaction of Lolium perenne and Hyphomicrobium sp. GHH enhances the removal of 17 $\alpha$-ethinyestradiol (EE2) from soil. J Soils Sedim 19:1297-1305. https://doi.org/10.1007/s11368-018-2116-y

Hill MK (2020) Understanding environmental pollution. Cambridge University Press

Ho YN, Hsieh JL, Huang CC (2013) Construction of a plant-microbe phytoremediation system: combination of vetiver grass with a functional endophytic bacterium, achromobacter xylosoxidans F3B, for aromatic pollutants removal. Bioresour Technol 145:4347. https://doi.org/10.1016/j.biortech.2013.02.051

Hussain I, Aleti G, Naidu R et al (2018) Microbe and plant assistedremediation of organic xenobiotics and its enhancement by genetically modified organisms and recombinant technology: a review. Sci Total Environ 628-629:1582-1599. https://doi.org/10.1016/j. scitotenv.2018.02.037

Iqbal A, Mukherjee M, Rashid J et al (2019) Development of plantmicrobe phytoremediation system for petroleum hydrocarbon degradation: an insight from alkb gene expression and phytotoxicity analysis. Sci Total Environ 671:696-704. https://doi.org/10. 1016/j.scitotenv.2019.03.331

Irga PJ, Shagol CC, Kim KJ, Pettit T, and Torpy FR (2020) Plantmicrobe interaction within phytosystems used for air treatment. In: From biofiltration to promising options in gaseous fluxes biotreatment. INC. https://doi.org/10.1016/b978-0-12-819064-7.00012-1

Jenardhanan P, Panneerselvam M, Mathur PP (2016) Effect of environmental contaminants on spermatogenesis. Semin Cell Dev Biol 59:126-140. https://doi.org/10.1016/j.semcdb.2016.03.024

Jiang Q, Song X, Liu J et al (2019) Enhanced nutrients enrichment and removal from eutrophic water using a self-sustaining in situ photomicrobial nutrients recovery cell (PNRC). Water Res 167:115097. https://doi.org/10.1016/j.watres.2019.115097

Jin Y, Wu S, Zeng Z, Fu Z (2017) Effects of environmental pollutants on gut microbiota. Environ Pollut 222:1-9. https://doi.org/10. 1016/j.envpol.2016.11.045

Kanat G, Erguven G (2020) Importance of solid waste management on composting problems and proposed solutions: the case of Turkey. Eur J Sci Technol. https://doi.org/10.31590/ejosat.672413

Kanat G, Ikizoglu B, Erguven GO, Akgun B (2018) Determination of pollution and heavy metal fractions in golden horn sediment sludge (Istanbul, Turkey). Polish J Environ Stud 27:2605-2612. https://doi.org/10.15244/pjoes/80805

Khaksar G, Treesubsuntorn C, Thiravetyan P (2016) Endophytic Bacillus cereus ERBP-Clitoria ternatea interactions: potentials for the enhancement of gaseous formaldehyde removal. Environ Exp Bot 126:10-20. https://doi.org/10.1016/j.envexpbot.2016.02.009

Kristanti RA, Toyama T, Hadibarata T et al (2014) Sustainable removal of nitrophenols by rhizoremediation using four strains of bacteria and giant duckweed (Spirodela polyrhiza). Water Air Soil Pollut. https://doi.org/10.1007/s11270-014-1928-7

Kuiper I, Lagendijk EL, Bloemberg GV, Lugtenberg BJJ (2004) Rhizoremediation: a beneficial plant-microbe interaction bioremediation: a natural method. Mol Plant-Microbe Interact 17:6-15

Kurt OK, Zhang J, Pinkerton KE (2016) Pulmonary health effects of air pollution. Curr Opin Pulm Med 22:138-143. https://doi.org/ 10.1097/MCP.0000000000000248

Landrigan PJ, Fuller R (2015) Global health and environmental pollution. Int J Public Health 60:761-762. https://doi.org/10.1007/ s00038-015-0706-7
Lee BXY, Hadibarata T, Yuniarto A (2020) Phytoremediation mechanisms in air pollution control: a review. Water Air Soil Pollut 231:437. https://doi.org/10.1007/s11270-020-04813-6

Li H, Zhao HP, Hao HL et al (2011) Enhancement of nutrient removal from eutrophic water by a plant-microorganisms combined system. Environ Eng Sci 28:543-554. https://doi.org/10.1089/ees. 2011.0026

Liu L, Jiang CY, Liu XY et al (2007) Plant-microbe association for rhizoremediation of chloronitroaromatic pollutants with Comamonas sp. strain CNB-1. Environ Microbiol 9:465-473. https:// doi.org/10.1111/j.1462-2920.2006.01163.x

Ma Y, Oliveira RS, Wu L et al (2015) Inoculation with metal-mobilizing plant-growth-promoting rhizobacterium bacillus sp. SC2b and its role in rhizoremediation. J Toxicol Environ Heal-Part A Curr Issues 78:931-944. https://doi.org/10.1080/15287394. 2015.1051205

Mandal A, Thakur JK, Sahu A, Bhattacharjya S, Manna MC, Patra AK (2016) Plant-microbe interaction for the removal of heavy metal from contaminated site. In: Choudhary D, Varma A, Tuteja $\mathrm{N}$ (eds) Plant-microbe interaction: an approach to sustainable agriculture. Springer, Singapore. https://doi.org/10.1007/978981-10-2854-0_11

Mishra A, Mishra SP, Arshi A et al (2020) Plant-microbe interactions for bioremediation and phytoremediation of environmental pollutants and agro-ecosystem development. Bioremediation Ind Waste Environ Saf. https://doi.org/10.1007/978-981-13-34269_17

Muhammad S, Long X, Salman M (2020) COVID-19 pandemic and environmental pollution: a blessing in disguise? Sci Total Environ 728:138820. https://doi.org/10.1016/j.scitotenv.2020.138820

Nadalig T, Farhan Ul Haque M, Roselli S et al (2011) Detection and isolation of chloromethane-degrading bacteria from the Arabidopsis thaliana phyllosphere, and characterization of chloromethane utilization genes. FEMS Microbiol Ecol 77:438-448. https://doi. org/10.1111/j.1574-6941.2011.01125.x

Nasr M (2019) Environmental perspectives of plant-microbe nexus for soil and water remediation. In: Kumar V, Prasad R, Kumar M, Choudhary D (eds) Microbiome in plant health and disease. Springer, Singapore. https://doi.org/10.1007/978-981-13-8495$0 \_18$

Ndeddy Aka RJ, Babalola OO (2016) Effect of bacterial inoculation of strains of pseudomonas aeruginosa, alcaligenes feacalis and bacillus subtilis on germination, growth and heavy metal $(\mathrm{cd}, \mathrm{cr}$, and ni) uptake of brassica juncea. Int J Phytoremediation 18:200-209. https://doi.org/10.1080/15226514.2015.1073671

Nowak DJ, Hirabayashi S, Bodine A, Greenfield E (2014) Tree and forest effects on air quality and human health in the United States. Environ Pollut 193:119-129. https://doi.org/10.1016/j.envpol. 2014.05.028

Ontañon OM, González PS, Ambrosio LF et al (2014) Rhizoremediation of phenol and chromium by the synergistic combination of a native bacterial strain and Brassica napus hairy roots. Int Biodeterior Biodegrad 88:192-198. https://doi.org/10.1016/j.ibiod. 2013.10.017

Pajewska-Szmyt M, Sinkiewicz-Darol E, Gadzała-Kopciuch R (2019) The impact of environmental pollution on the quality of mother's milk. Environ Sci Pollut Res 26:7405-7427. https://doi.org/10. 1007/s11356-019-04141-1

Pan F, Meng Q, Luo S et al (2017) Enhanced Cd extraction of oilseed rape (Brassica napus) by plant growth-promoting bacteria 
isolated from Cd hyperaccumulator Sedum alfredii Hance. Int J Phytoremediation 19:281-289. https://doi.org/10.1080/15226514. 2016.1225280

Pandey A, Tripathi A, Srivastava P et al (2019) Plant growth-promoting microorganisms in sustainable agriculture. Elsevier, Amsterdam

Pheomphun P, Treesubsuntorn C, Jitareerat P, Thiravetyan P (2019) Contribution of Bacillus cereus ERBP in ozone detoxification by Zamioculcas zamiifolia plants: effect of ascorbate peroxidase, catalase and total flavonoid contents for ozone detoxification. Ecotoxicol Environ Saf 171:805-812. https://doi.org/10.1016/j. ecoenv.2019.01.028

Pizarro-Tobias P, Niqui JL, Roca A et al (2015) Field trial on removal of petroleum-hydrocarbon pollutants using a microbial consortium for bioremediation and rhizoremediation. Environ Microbiol Rep 7:85-94. https://doi.org/10.1111/1758-2229.12174

Sakshi SSK, Haritash AK (2019) Polycyclic aromatic hydrocarbons: soil pollution and remediation. Int J Environ Sci Technol 16:6489-6512. https://doi.org/10.1007/s13762-019-02414-3

Salam JA, Hatha MAA, Das N (2017) Microbial-enhanced lindane removal by sugarcane (Saccharum officinarum) in doped soilapplications in phytoremediation and bioaugmentation. J Environ Manage 193:394-399. https://doi.org/10.1016/j.jenvman.2017.02. 006

Sánchez-Pérez BN, Zenteno-Rojas A, Rincón-Molina CI et al (2020) Rhizosphere and endophytic bacteria associated to Ocimum basilicum L with decaclorobiphenyl removal potential. Water Air Soil Pollut. https://doi.org/10.1007/s11270-020-04481-6

Saravanan A, Jeevanantham S, Narayanan VA et al (2020) Rhizoremediation-A promising tool for the removal of soil contaminants: a review. Elsevier, Amsterdam

Sarma H, Sonowal S, Prasad MNV (2019) Plant-microbiome assisted and biochar-amended remediation of heavy metals and polyaromatic compounds-a microcosmic study. Ecotoxicol Environ Saf 176:288-299. https://doi.org/10.1016/j.ecoenv.2019.03.081

Sauvêtre A, May R, Harpaintner R et al (2018) Metabolism of carbamazepine in plant roots and endophytic rhizobacteria isolated from Phragmites australis. J Hazard Mater 342:85-95. https://doi. org/10.1016/j.jhazmat.2017.08.006

Shahid MJ, Ali S, Shabir G et al (2020) Comparing the performance of four macrophytes in bacterial assisted floating treatment wetlands for the removal of trace metals $(\mathrm{Fe}, \mathrm{Mn}, \mathrm{Ni}, \mathrm{Pb}$, and $\mathrm{Cr}$ ) from polluted river water. Chemosphere. https://doi.org/10.1016/j.chemo sphere.2019.125353

Shi L, Deng X, Yang Y et al (2019) A Cr(VI)-tolerant strain, Pisolithus sp1, with a high accumulation capacity of $\mathrm{Cr}$ in mycelium and highly efficient assisting Pinus thunbergii for phytoremediation. Chemosphere 224:862-872. https://doi.org/10.1016/j.chemo sphere.2019.03.015

Simón Solá MZ, Lovaisa N, Dávila Costa JS et al (2019) Multi-resistant plant growth-promoting actinobacteria and plant root exudates influence $\mathrm{Cr}(\mathrm{VI})$ and lindane dissipation. Chemosphere 222:679687. https://doi.org/10.1016/j.chemosphere.2019.01.197

Sriprapat W, Thiravetyan P (2016) Efficacy of ornamental plants for benzene removal from contaminated air and water: effect of plant associated bacteria. Int Biodeterior Biodegrad 113:262-268. https://doi.org/10.1016/j.ibiod.2016.03.001
Srivastava JK, Chandra H, Kalra SJS et al (2017) Plant-microbe interaction in aquatic system and their role in the management of water quality: a review. Appl Water Sci 7:1079-1090. https://doi.org/10. 1007/s13201-016-0415-2

Supreeth M, Raju N (2017) Biotransformation of chlorpyrifos and endosulfan by bacteria and fungi. Appl Microbiol Biotechnol 101:5961-5971. https://doi.org/10.1007/s00253-017-8401-7

Suyamud B, Thiravetyan P, Panyapinyopol B, Inthorn D (2018) Dracaena sanderiana endophytic bacteria interactions: effect of endophyte inoculation on bisphenol a removal. Ecotoxicol Environ Saf 157:318-326. https://doi.org/10.1016/j.ecoenv.2018.03.066

Tatar S, Yildirim NC, Serdar O, Erguven GO (2020) Can toxicities induced by insecticide methomyl be remediated via soil bacteria Ochrobactrum thiophenivorans and Sphingomonas melonis? Curr Microbiol 77:1301-1307. https://doi.org/10.1007/ s00284-020-02042-y

Thakur M (2018) Paradigms in pollution prevention. Springer, Cham, pp 61-70. https://doi.org/10.1007/978-3-319-58415-7

Truu J, Truu M, Espenberg M et al (2015) Send orders for reprints to reprints@benthamscience.ae phytoremediation and plant-assisted bioremediation in soil and treatment wetlands: a review. Open Biotechnol J 9:85-92

Wang Y, Oyaizu H (2011) Enhanced remediation of dioxins-spiked soil by a plant-microbe system using a dibenzofuran-degrading Comamonas sp. and Trifolium repens L. Chemosphere 85:1109-1114. https://doi.org/10.1016/j.chemosphere.2011.07.028

Wang Z, Pei J, Zhang JS (2014) Experimental investigation of the formaldehyde removal mechanisms in a dynamic botanical filtration system for indoor air purification. J Hazard Mater 280:235-243. https://doi.org/10.1016/j.jhazmat.2014.07.059

Weyens N, van der Lelie D, Taghavi S et al (2009) Exploiting plantmicrobe partnerships to improve biomass production and remediation. Trends Biotechnol 27:591-598. https://doi.org/10.1016/j. tibtech.2009.07.006

Wu H, Xu K, He X, Wang X (2016) Removal of nitrogen by three plant species in hydroponic culture: plant uptake and microbial degradation. Water Air Soil Pollut. https://doi.org/10.1007/ s11270-016-3036-3

Xu X, Nie S, Ding H, Hou FF (2018a) Environmental pollution and kidney diseases. Nat Rev Nephrol 14:313-324. https://doi.org/10. 1038/nrneph.2018.11

Xu XJ, Lai GL, Chi CQ et al (2018b) Purification of eutrophic water containing chlorpyrifos by aquatic plants and its effects on planktonic bacteria. Chemosphere 193:178-188. https://doi.org/10. 1016/j.chemosphere.2017.10.171

Yan X, Huang J, Xu X, Chen D, Xie X, Tao Q, He JJJ (2018) Enhanced and complete removal of phenylurea herbicides by combinational transgenic plant-microbe remediation. Appl Environ Microbiol 84:1-16

Yang Y, Su Y, Zhao S (2020) Correction to: an efficient plant-microbe phytoremediation method to remove formaldehyde from air (Environmental Chemistry Letters (2020), 18, 1, (197-206), 10.1007/ s10311-019-00922-9). Environ Chem Lett 18:527. https://doi.org/ 10.1007/s10311-019-00941-6 
Yang Y, Su Y, Zhao S (2020a) An efficient plant-microbe phytoremediation method to remove formaldehyde from air. Environ Chem Lett 18:197-206. https://doi.org/10.1007/s10311-019-00922-9

Yildirim N, Erguven GO, Adar E (2018) The chemical and biochemical oxygen demand reduction by armillaria tabescens in malathion supplemented culture medium. Glob Nest J 20:529-533. https:// doi.org/10.30955/gnj.002660

Ying X, Dongmei G, Judong L, Zhenyu W (2011) Plant-microbe interactions to improve crude oil degradation. Energy Proc 5:844-848

Yutthammo C, Thongthammachat N, Pinphanichakarn P, Luepromchai E (2010) Diversity and activity of pah-degrading bacteria in the phyllosphere of ornamental plants. Microb Ecol 59:357-368. https://doi.org/10.1007/s00248-009-9631-8

Zhang H, Pennisi SV, Kays SJ, Habteselassie MY (2013) Isolation and identification of toluene-metabolizing bacteria from rhizospheres of two indoor plants. Water Air Soil Pollut 224:1-14. https://doi. org/10.1007/s11270-013-1648-4

Zhao S, Zhao Y, Liang H, Su Y (2019) Formaldehyde removal in the air by six plant systems with or without rhizosphere microorganisms. Int J Phytoremediation 21:1296-1304. https://doi.org/10. 1080/15226514.2019.1586036 